\title{
ECONNECT - Improving connectivity in the Alps Implementation in the pilot region Northern Limestone Alps
}

\author{
Daniel Kreiner, Alexander Maringer \& Lisbeth Zechner
}

Keywords: ECONNECT, white-backed woodpecker, Ural owl

\section{Abstract}

The three-year EU project ECONNECT with 16 partners was one of the largest international projects for improving ecologic connectivity in the Alps. Gesäuse National Park was ECONNECT partner and took advantage of the project to initiate a transparent planning process for ecologic connectivity in the region, working closely with Kalkalpen National Park and Dürrenstein Wilderness Area and involving a variety of stakeholders to an unprecedented degree. 160 structured interviews and numerous working groups were held. As a result, it was possible to involve several large forest owners in starting a process of promoting near-natural forests in an effort to protect the white-backed woodpecker.
Profile

Protected area

Gesäuse National Park

Mountain range

Alps

Country

\section{The pilot region Northern Limestone Alps: Eisenwurzen - Gesäuse - Dürrenstein}

The project area is shaped by its history as a cultural and economic region with more than 800 years of land use. Even today, the region forms a coherent whole. Formerly, the economic motor of the region was the production and processing of ore and metal, today this role has been taken over by agriculture, forestry and tourism.

The landscape of the Limestone Alps features striking mountain massifs with craggy walls of limestone and dolomite as well as wooded, softly undulating upland ranges. The pilot area includes large areas of low settlement density and little dissection, extensive forests $(>80 \%)$, an intricate patchwork of a cultural landscape with high species diversity, plus a large number of existing protected areas with a total acreage of over 200000 hectares. The region also serves as a link with the eastern foothills of the Alps and on towards the Carpathians, on the one hand, and to the protected areas further west (e.g. Dachstein, Hohe Tauern), on the other.

\section{Connecting habitats - connecting people}

The three-year EU project ECONNECT (ETC Alpine Space Programme), with 16 project partners, is the largest international project to date aimed at improving ecologic connectivity in the Alps. Suitable connectivity elements are existing protected areas plus landscape corridors of high biodiversity, which may be secured through projects or contract conservation. The aim is to recreate a cross-border ecosystem network in the Alps where man had put up barriers and borders in the past.

Nationalpark Gesäuse GmbH (Styria) was an ECONNECT project partner and started an ecological
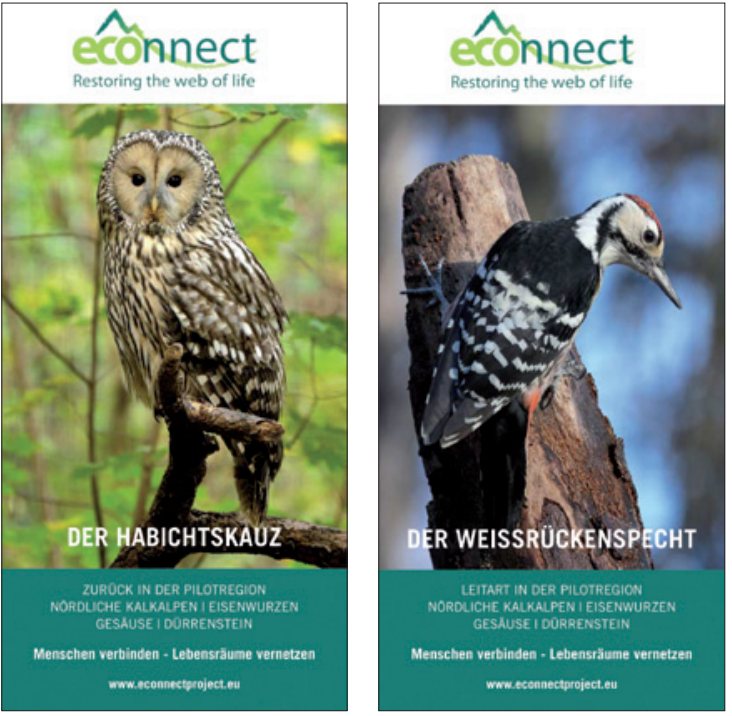

Figure 1 - Information folder on the white-backed woodpecker and the Ural owl.

continum in the region. To this end, it entered a transparent planning process of close cooperation with Kalkalpen NP (Upper Austria) and Dürrenstein Wilderness Area (Lower Austria). Great care was taken to involve all interested parties who wanted to cooperate in the project. These include the protected area administrations, land owners and holders of rights of use, representatives of agriculture and forestry, hunting and fishing, waterways engineering, torrent and avalanche control, spatial planning and regional development.

Initially, information events about the project were held in the federal provinces involved. At the same time, a project folder with a colourful representation of the pilot regions was created and distributed.

In the next step of the participation process, 160 people were interviewed in the three federal provinces. In Lower Austria, Dürrenstein Wilderness Area 


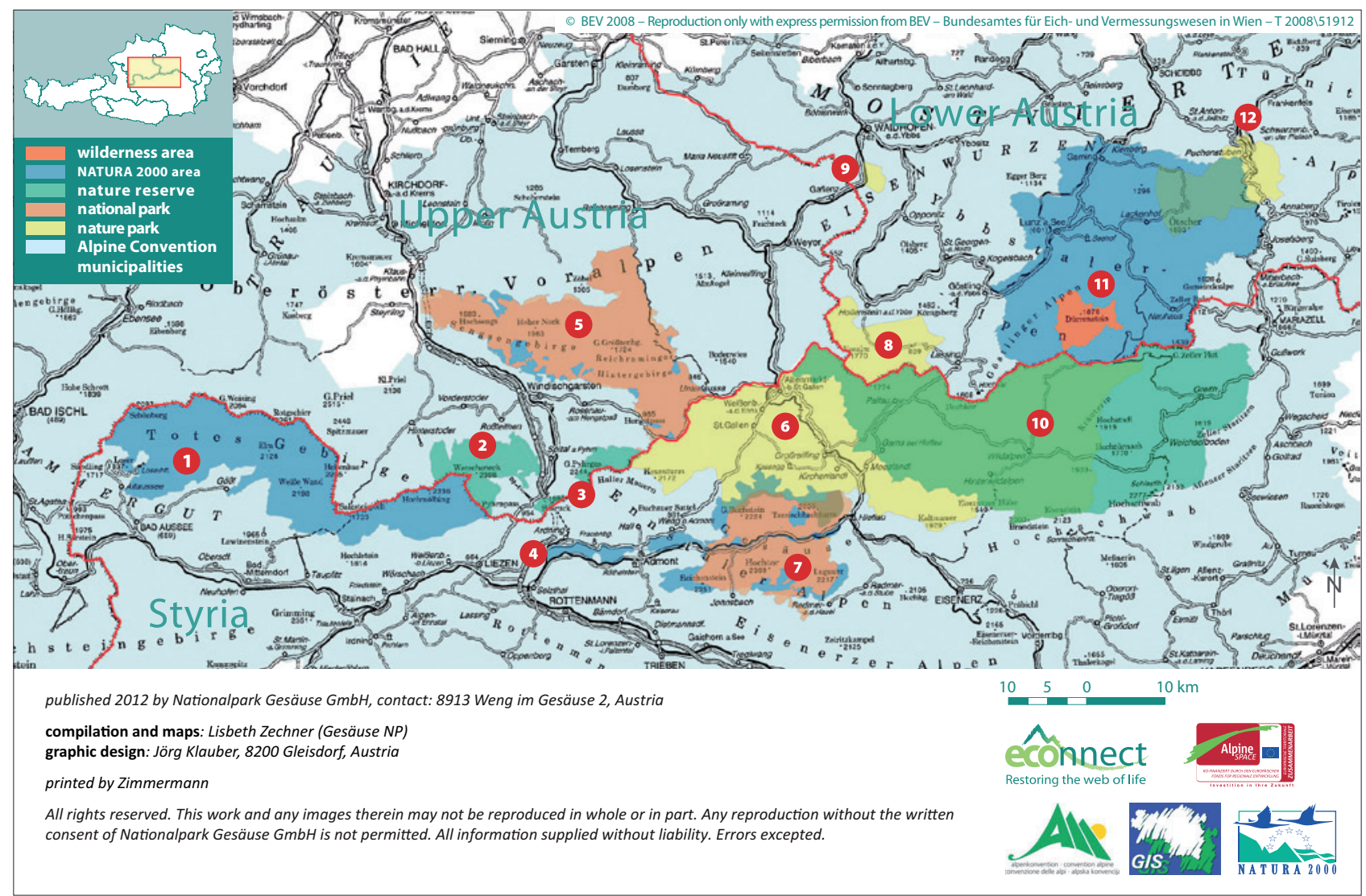

Figure 2 - Map of the pilot regions from the ECONNECT folder. Red dots: 1 Totes Gebirge; 2 Warscheneck; 3 Bosruck - Haller Mauern; 4 Pürgschachen Moos and riparian areas on the Enns; 5 Kalkalpen National Park; 6 Steirische Eisenwurzen Nature Park; 7 Gesäuse National Park; 8 Eisenwurzen Nature Park; 9 Buchenberg Nature Park; 10 Salzatal; 11 Dürrenstein Wilderness Area; 12 Ötscher-Tormäuer Nature Park. Red line: federal state border.

conducted the interviews, in Upper Austria, this was done by regional management and in Styria by Karin Hochegger. The data were entered into an Access database and analysed. Habitats or themes mentioned repeatedly as a priority for ecological connectivity measures included mountain pastures, extensively used meadows and keeping the landscape open. Two further thematic fields relate to promoting near-natural forest communities, protective forest projects including hoofed game management as well as maintaining and renaturating rivers and riparian woodland. A majority of interviewees was interested in the theme, wanted more information material and a smaller group even wanted to continue to cooperate (Hochegger \& Nadlinger 2009).

On the basis of these results, four thematic workshops were organized on the key themes of forest, mountain pastures (and extensive grassland), bodies of water and public relations. These working groups developed concrete project content with potential project partners, which were eventually integrated into an overall project.

These efforts resulted in a project proposal called VeuER (= Vernetzen und Erleben, or: connectand experience). This proposal envisaged a thematic long-distance trail, integrated into an existing trail network, that would connect individual measures (e.g. connecting the biotopes of the white-backed woodpecker, renaturating streams, etc.) and allow people to experience connectivity. Other measures, such as the Electronic Almguide, would have included added tourist value to benefit not just nature but also the region and its inhabitants. In addition there was the vision of creating a strong brand Nature Region that would stand for special natural features, quality and sustainability and support the regional economy. As it was impossible to open up national funding for this project, a new approach had to be found (Hoffert 2011).

The implementation projects: from the white-backed woodpecker to the Ural owl

The white-backed woodpecker project started by inviting the large land owners in the region to get involved in a joint project to improve the habitat situation of the white-backed woodpecker. In addition to the three protected areas Gesäuse NP, Dürrenstein Wilderness Area and Kalkalpen NP, the following enterprises joined in: Austrian Federal Forests (ÖBf), Styrian Forests and the Forestry Office and Agricultural Operations of the City of Vienna, MA 49 (Wildalpen Forestry Administration). There followed a lively exchange of information on the project, a short introduction of the proposal was sent out (Zechner 
2011), including an appeal to the forestry enterprises to provide data for habitat modelling with MaxEnt (Phillips 2008). The data were gathered in Gesäuse NP and passed on to an external GIS specialist for further action. By early May, the results had been converted into a map of suitable habitats for the white-backed woodpecker (Kammerer 2011a). Later, excursions were organized in the various forestry administrations to raise awareness and at the same time to check on the modelling results. After these inspections, a joint event was organized to discuss further actions and to present the project report of the Austrian Federal Forests on their experiences (Lassnig 2011).

In September 2011, a coordination meeting was held in Gesäuse NP with the partners involved in the project and the biologists. The needs of the whitebacked woodpecker in the pilot region were presented and the partners agreed a cooperation to establish it as the key species for beech forests rich in deadwood. Reports from the individual enterprises helped in formulating the goals and measures.

These were broken down into the following work packages (WP):

1. Partners' expression of intent to support the whitebacked woodpecker, to protect its habitat and to keep it in near-natural condition

2. Fine-tuning of the habitat model on the basis of new requirements

3. Workshop to raise the awareness of staff

4. Establishing a monitoring network

5. PR efforts plus creating an information folder

WP 1: Partners' expression of intent: Agreement on the protection of the white-backed woodpecker

The agreement was drawn up jointly and signed by the partners on 29.11.2011. Key points include:

1. Joint PR

2. Optional collaboration in capturing the distribution of the white-backed woodpecker as part of forestry operations in selected territories

3. Collaboration in establishing a joint working group on the white-backed woodpecker

4. Collaboration in the working groups and exchange of information

5. Establishing a potentially natural forest community within contemporary forest management on a voluntary basis while taking economic objectives into account

6. Leaving more forest-hygienically harmless deadwood in forest regions with significant deadwood deficit, plus maintaining islands of old wood and deadwood in managed forests within the possibilities of economic feasibility

7. These measures are to be implemented voluntarily and effectively, with minimal impact on operational processes, but may require additional expenditure

8. An evaluation of the agreed objectives to be carried out five years after the agreement was signed

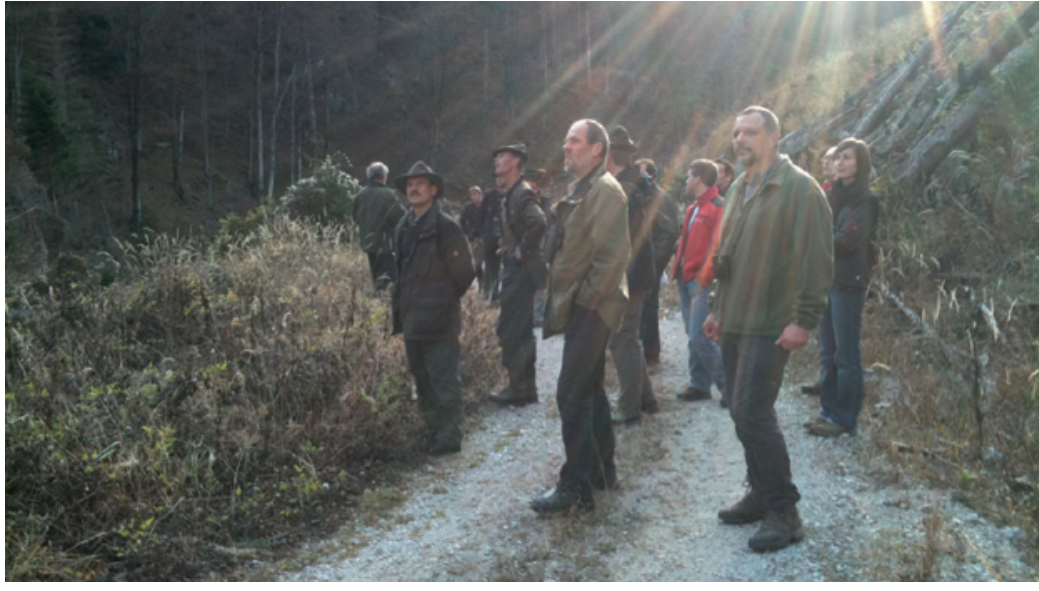

Figure 3 - Joint inspection of potential white-backed woodpecker habitats aimed to inform about the species' needs and served to discuss potential measures within forest management. (C) Daniel Kreiner

\section{WP 2: Fine-tuning of the habitat model}

Fine-tuning the habitat modelling aimed at sharpening the results of the first modelling and making them more precise. The white-backed woodpecker often uses older trees to build its breeding burrow. Assuming that protective forests (managed and unmanaged) contain a larger number of older trees, these data were integrated into the existing model as additional parameters.

The results of the MaxEnt modelling shows very low correlation between protective forest areas and observed distribution of the white-backed woodpecker. The enlarged parameterization identified greater areas of potentially suitable habitats. Only a small percent-

\section{Infobox}

\section{ECONNECT - Improving Connectivitiy in the Alps}

Duration: September 2008 - November 2011

16 project partners across the Alps, lead partner: University of Veterinary Medicine, Vienna, Research Institute of Wildlife Ecology (FIWI)

\section{7 pilot regions}

- the cross-border region Berchtesgaden - Salzburg

- the French Département Isère

- the Northern Limestone Alps region

- the Rhaethian Triangle (Engadin/South Tyrol/Trentino/ Tyrolean Etschtal)

- the Hohe Tauern region

- the South-western Alps - Mercantour/Alpi Marittime

- the Monte Rosa region

\section{Overall budget: EUR 3.2 million}

EU funding for the project was $76 \%$ of total cost.

In the pilot region Northern Limestone Alps, the remaining cost was covered by contributions in kind from the protected area administrations of Gesäuse National Park (NP), Kalkalpen NP and Dürrenstein Wilderness Area. 


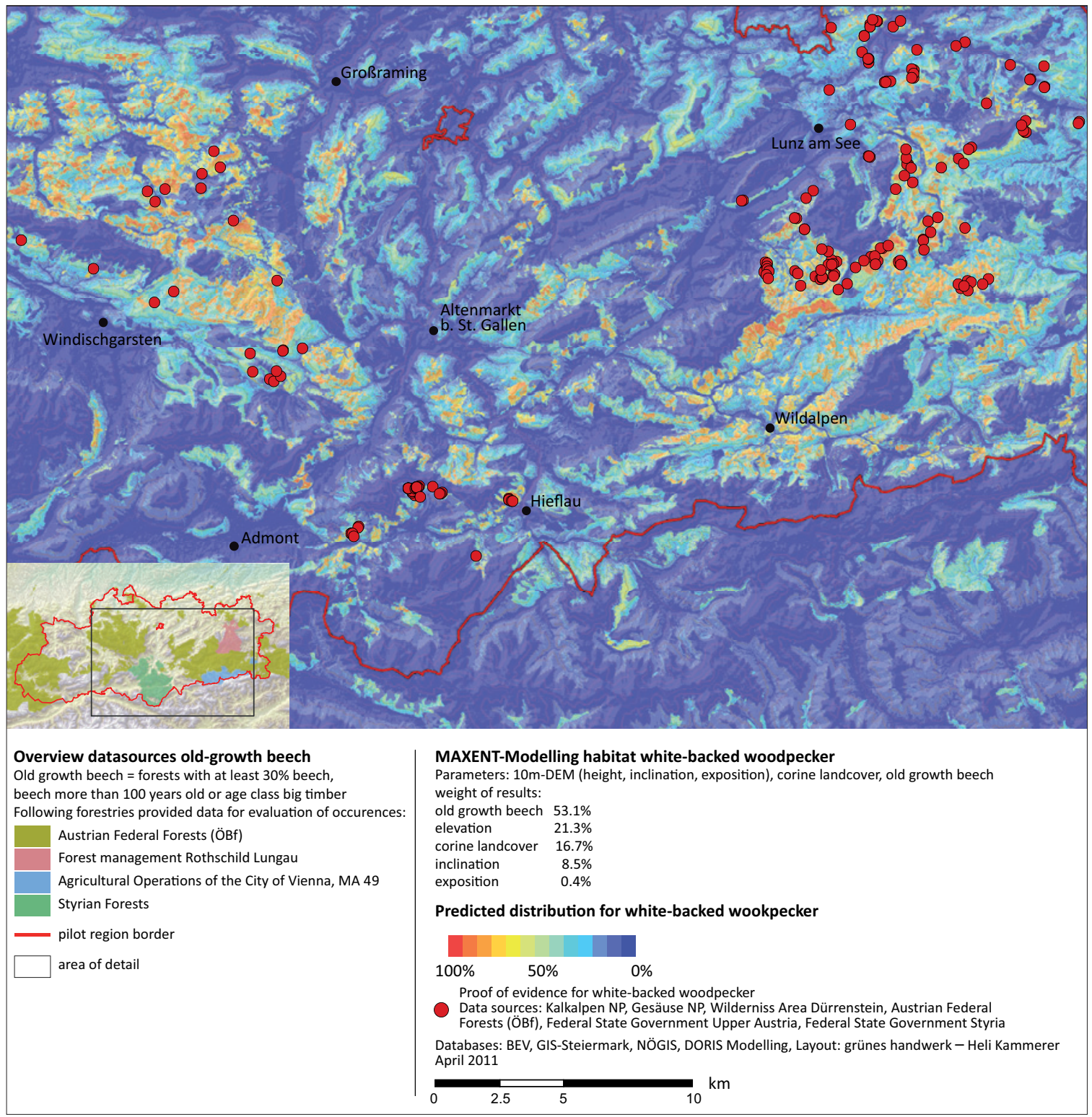

Figure 4 - Isolated areas of high probability for the occurence of the white-backed woodpecker (section).

age of the observed distribution falls into managed or unmanaged protective forests (Kammerer 2011c).

Another map serves to identify the highly suitable habitats in relation to the position of the managed and unmanaged protective forests (Kammerer 2011d). It shows that the best white-backed woodpecker habitats are very isolated. The low overlap with protective forests indicates that habitat protection of the whitebacked woodpecker cannot be ensured through protective forests alone. This means further that there is a need to improve larger areas as foreseen by the Agreement on the protection of the white-backed woodpecker, at least on a voluntary basis.

By processing more comprehensive existing forest data, one could arrive at a more detailed analysis and develop the modelling of suitable habitats further by stratifying the operational data in terms of tree species composition and age. This would improve the input parameters for the MaxEnt modelling and could sharpen the suitable habitat map considerably.
WP 3: Workshop to raise staff awareness

Staff from the Austrian Federal Forests, Styrian Forests, Kalkalpen NP, Gesäuse NP and Dürrenstein Wilderness Area attended a workshop in which ornithologists explained the habitat requirements of the white-backed woodpecker and the measures to establish it as key species for the pilot region. It also served to initiate a monitoring network.

\section{WP 4: Monitoring network}

Trained staff of the partner institutions will start to capture the occurrence of the white-backed woodpecker using homogenized methods. These data will be gathered and, together with existing dissemination data, made available for further modelling and analysis.

\section{WP 5: PR efforts}

An information folder has been created to promote the joint measures. It aims to inform the population about the white-backed woodpecker and its ecologic 
function and to encourage more forest owners to participate within the project.

\section{Improved networking within the existing Ural owl project}

The ECONNECT project also spawned new collaboration within an already running project of reintroducing the Ural owl. The FIWI project of reintroducing the Ural owl had led to the identification of some individuals in the vicinity of Gesäuse NP. Now, nesting boxes were put up at suitable places to encourage the dissemination of the species in the pilot region Northern Limestone Alps.

It became clear that the introduced Ural owls are active across large parts of the pilot region, which makes closer cooperation between the coordinating institution of the Ural owl reintroduction project in Dürrenstein Wilderness Area and other partners in the region desirable.

As a first step towards a better selection of suitable sites for the nesting boxes, the probability of occurrence was modelled using MaxEnt (see white-backed woodpecker) (Kammerer 2011b). In particular, more nesting boxes were put up in the pilot region. They replace the breeding burrows which are not available in sufficient numbers. Overall, 20 additional nesting boxes were installed in the region. In the course of this work, talks were held with the land owners and excursions organized to select suitable trees on the land of the Styrian Forests. A separate folder was developed and distributed via the protected area administrations to get more land owners and interested parties involved.

In Kalkalpen NP and in Gesäuse NP, forest management will improve habitats in the medium term. After a transition phase, the Ural owls will thus find natural breeding burrows in old trees. A similar positive effect could be achieved by adapted management in the forestry enterprises (see Agreement on the protection of the white-backed woodpecker, above).

PR efforts within these activities received a positive echo and numerous media reported on the nesting box initiative in Gesäuse NP.

Additional initiatives included genetic studies of capercaillie populations at the edge of Gesäuse NP to check on the genetic exchange between these populations and those outside the national park. These aimed at better coordinated management to boost the vitality of the populations (Grünschachner-Berger \& Hirschenhauser 2011).

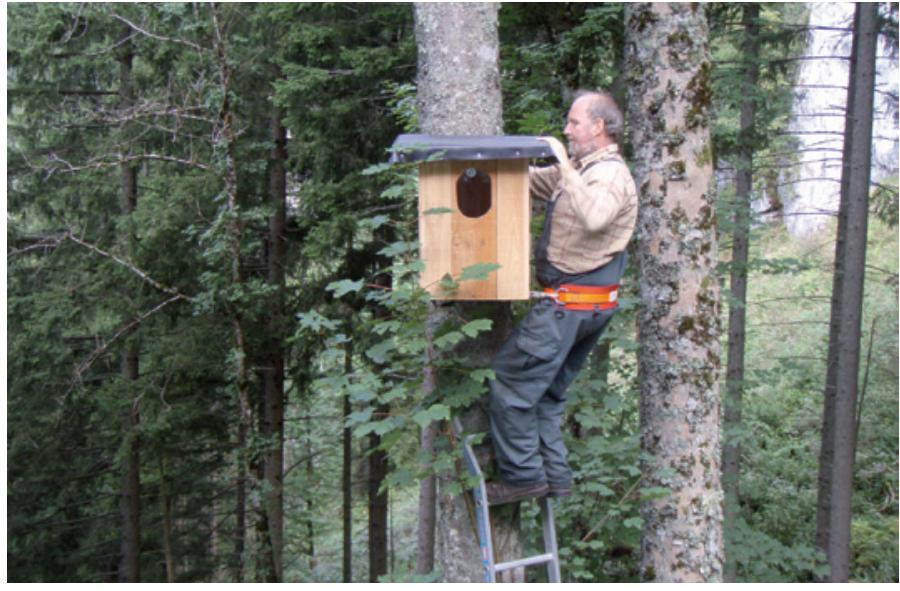

Figure 5 - Putting up a nesting box for the Ural owl. (C) Daniel Kreiner

In addition, intensive PR networking was planned for 2012 with joint events such as the Parks Day and Species Diversity Day at a renaturated river section.

A priority for the future seems to be the continuation of existing good approaches in a number of followup projects. Kalkalpen NP, Gesäuse NP, Dürrenstein Wilderness Area and the forestry enterprises involved will certainly continue to be active in supporting the initiatives on habitat connectivity and on connecting humans. The future of these regional projects lies in intensified cooperation of diverse interest groups.

\section{References}

Grünschachner-Berger, V. \& K. Hirschenhauser 2011. Genetisches Bestandsmonitoring von Auerbübnern am Gscheidegg. Bericht im Auftrag des Nationalpark Gesäuse. Part of the Alpine Space Program (European Fonds for Regional Development), Econnect and NATURA 2000.

Hoffert, H., D. Kreiner \& L. Zechner 2011. Projektexposee „VEuER“Pilotregion nördliche Kalkalpen.

Lassnig, C. 2011. Bericht Schutzmaßnabmen für den Weißrückenspecht - Vorarbeiten in der Pilotregion von ECONNECT.

Phillips, S.J. \& M. Dudik 2008. Modeling of species distributions with Maxent: new extensions and a comprehensive evaluation. Ecography 31: 161-175.

Zechner L. 2011. ECONNECT-Umsetzungsprojekt Weißrückenspecht - Kuržbeschreibung

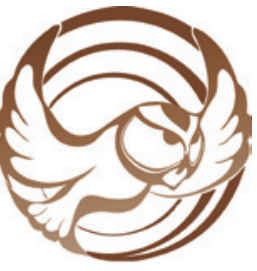

WILDNIS

DÜRRENSTEIN

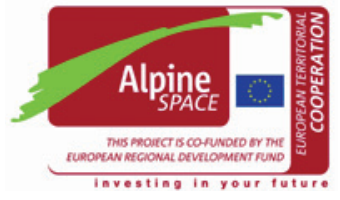


Maps

Kammerer, H. 2011a. MAXENT Modellierung Lebensraum Weißrückenspecht

Kammerer, H. 2011b. MAXENT Modellierung Lebensraum Habichtskauz

Kammerer, H. 2011c. MAXENT Modellierung

Lebensraum Weißrückenspecht v2

Kammerer, H. 2011d. MAXENT Modellierung Lebensraum Weißrückenspecht v2_SWiaE

Selected links

ECONNECT: www.econnectproject.eu

Project region: www.umweltbundesamt.at/umwelt schutz/

Gesäuse National Park: www.nationalpark.co.at

Dürrenstein Wilderness Area: www.wildnisgebiet.at

Kalkalpen National Park: www.kalkalpen.at

Austrian Nature Parks: www.naturparke.at

Nature Parks Lower Austria: www.naturparkenoe.at

Alpine Network of Protected Areas: www.alparc.org

Ecological networks in the European Alps: www.alpine-ec-

ological-network.org

CIPR A International: www.cipra.org/de

\section{Authors}

\section{Daniel Kreiner}

born 1972. Degree in botany (University Graz) and geographical information science and systems (University Salzburg). Works on habitat mapping and evaluation of nature conservation value, GIS mapping and modelling. Since 2003 employed at Gesäuse NP, responsible for nature conservation matters and research. Project leader of the LIFE Nature project Conservation strategies for woodlands and rivers in the Gesäuse Mountains and, since 2011, responsible for the implementation measures in the ECONNECT project in the pilot region Northern Limestone Alps.

email: daniel.kreiner@nationalpark.co.at

\section{Alexander Maringer}

studied ecology at the University of Salzburg and graduated in 2005. He focused on beavers and thus conflict management in human-dominated landscapes. He worked on projects in nature conservation, GIS modelling and environmental education before starting at Gesäuse NP. In June 2011, he joined the ECONNECT project team in the pilot region Northern Limestone Alps and implemented several work packages on the white-backed woodpecker and Ural owl. email: alexander.maringer@nationalpark.co.at

\section{Lisbeth Zechner}

studied zoology (University Graz). She obtained her degrees with a thesis on Settling Biology and Reproduction of Golden Eagles and on Grasshopper Fauna in selected habitats. From 1995 onwards, she worked on various breeding bird and grasshopper surveys, partly in connection with changes in farming, mapping of birds of prey and of threatened bird species, also contributing to various nature and bird protection projects.

Since 2004 in the Gesäuse NP; main topics of fieldwork were surveys of bird and grasshopper communities. She developed the visitor management plan for Gesäuse NP and was project leader of the ECONNECT project in the pilot region Northern Limestone Alps until 2010.

In 2011, she changed to the Parc naturel régional du Massif des Bauges, where she works as project leader and expert on fauna in the hunting and wildlife conservation area.

email:1.zechner@parcdesbauges.com 